Original Research Paper

\title{
A Vital Source of Energy for 21st Century: Review On Alkaline Fuel Cell
}

\author{
Omprakash Sahu and Suddhasatwa Basu
}

Department of Chemical Engineering, Institute of Technology Delhi, Hauz-Khas New-Delhi, New Delhi 110016, India

\author{
Article history \\ Received: 2014-07-08 \\ Revised: 2014-07-29 \\ Accepted: 2014-11-25 \\ Corresponding Author: \\ Omprakash Sahu, \\ Department of Chemical Engineering, \\ Institute of Technology Delhi, Hauz- \\ Khas New-Delhi, \\ New Delhi 110016, India \\ Email: ops0121@gmail.com
}

\begin{abstract}
A cell which converts the chemical energy into electric energy as eco-friendly way on the principle of electrochemical and Inverted by Sir William Grove in 1839 is known to be "fuel cell". It became a vital source of energy for the 21 st Century. Different types of fuel cell are invented based on their working temperature and a type of material has been used in which alkaline fuel cell is one of the best. Fuel cell is an electro-chemical energy converter at the simplest conceptual level it's combined hydrogen with oxygen to produced water and electricity. It does not store the energy itself. It is flow process which draws liquid or gaseous fuel from separated tank and if necessary converse it to hydrogen in reformer. The hydrogen is taken combined with oxygen air in the fuel cell to produced water and electricity. The energy conversion process in the fuel cell is therefore intrinsically clean and silent. Generally other fuel such as natural gas, methanol, ethanol and even coal can also be used. The object of this study is to summarize the characteristic of the alkaline fuel cell.
\end{abstract}

Keywords: Fuel Cell, Ethanol, Alcohol, Current, Voltage

\section{Introduction}

Fuel Cell is an electrochemical device which converts chemical energy into electrical energy in an eco-friendly manner. It is based on the principle of electrochemical reaction. Fuel Cell was invented by Sir William Grove in 1839. This is shown in Fig. 1.

Many research works is going worldwide in the area of "Fuel Cell" as a promising vital source of energy for the 21 st century. It is well known that conventional energy is exhaustible and ends up within a few years. The other source of energy is the nonconventional, or renewable energy source that is being produced by the nature continuously. There are many types of non-conventional energy, e.g., wind energy, solar energy, hydro-energy, tidal energy. Fuel Cell is one of the best forms of renewable energy sources. Many types of fuel cell are invented depending on the nature of the electrolyte and the electrodes, the cell architecture, the use of temperature range and the applications. Alkaline Fuel Cell (AFC) is the most studied and used fuel cell.
Alkaline fuel cell was first invented by NASA in 1960 for Apollo's shuttle mission that generated electric city as well as drinking water. Fuel cell is an electro-chemical energy converter at the simplest conceptual level. It combines hydrogen with oxygen to produce water and electricity. It does not store the energy in itself. It is a flow process which draws liquid or gaseous fuel from separated tank and if necessary converts it to hydrogen in reformer.

The hydrogen is taken combined with oxygen air in the fuel cell to produce water and electricity. The energy conversion process in the fuel cell is therefore intrinsically clean and silent. Generally other fuel such as natural gas, methanol, ethanol and even coal can also be used.

\section{Reaction}

Alkaline fuel cell operates on hydrogen and oxygen and a solution of potassium hydroxide as the electrolyte. The main cell has two parts; anode and cathode and the electrolyte are sandwiched between them.

At the anode, the hydrogen is catalytically oxidised:

$$
2 \mathrm{H}_{2}+4 \mathrm{OH}^{-} \rightarrow 4 \mathrm{H}_{2} \mathrm{O}+4 \mathrm{e}^{-}
$$




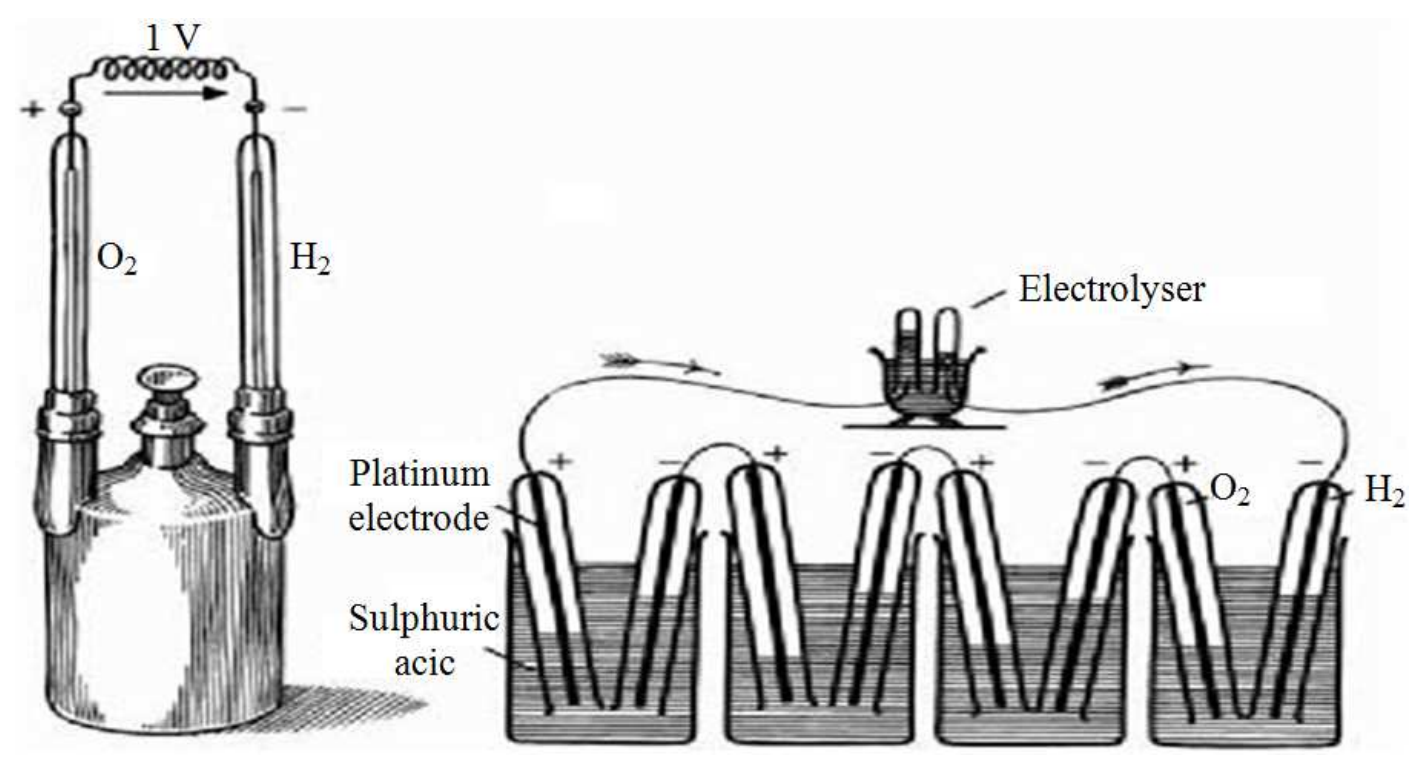

Fig. 1. Arrangement of basic fuel cell

At the cathode the oxygen is catalytically reduced:

$$
\mathrm{O}_{2}+2 \mathrm{H}_{2} \mathrm{O}+4 \mathrm{e}^{-} \rightarrow 4 \mathrm{OH}^{-}
$$

The overall cell reaction becomes:

$$
2 \mathrm{H}_{2}+\mathrm{O}_{2} \rightarrow 2 \mathrm{H}_{2} \mathrm{O}+\text { electric energy }+ \text { heat }
$$

In the cell reaction hydroxyl ion are charge carrier in electrolyte and they migrate from the cathode to the anode. At anode hydrogen gas react with the $\mathrm{OH}$-to produce water and releases electron. Electrons are generated at anode connected to the external circuit and migrate to the cathode. These electrons react with the oxygen at cathode to produce hydroxyl ion that diffuses into the electrolyte for the further reaction.

\section{Cell Reaction}

The reaction between two electrodes in the presence of an electrolyte is defined as "cell reaction". In fuel cell different kind of catalysts are used for the preparation of anode and cathode. Electrolyte is either in mobile form or in stationary form it depends upon the type of the model.

\section{Anode Electrode}

The anode electrode catalyst material is one of the important components of the alkaline fuel cell for the electro-oxidation of fuel. It is desirable that the anode electrode catalyst should provide faster reaction kinetic and $100 \%$ oxidation of carbonaceous fuel to $\mathrm{CO}_{2}$ and $\mathrm{H}_{2} \mathrm{O}$. The most commonly used technique in electro-chemical study of fuel cell reaction has been cyclic voltammerty.
The cyclic voltammerty is used to study the redox behavior of electrode in fuel electrolyte solution.

In search of suitable electrode (Morallon et al., 1995; Tripkovic et al., 2001; Wang et al., 2003) studied the methanol electro-oxidation on $\mathrm{Pt}$ in carbonate, bicarbonate and $\mathrm{NaOH}$ solution to compare the result. They have found that the methanol oxidation on Pt (111) catalyst is slower in bicarbonate and carbonate solution than in $\mathrm{NaOH}$ solution. Tripkovic et al. (2001) carried out on a PT (111) surface in different concentration of the $\mathrm{NaOH}$ solution. The CVs of Pt (111) electrode in the three different concentration of $\mathrm{NaOH}$ solution (without methanol) were showing two separation well defined zone. The first Zone in the potential range of. $06 \mathrm{~V}-0.4 \mathrm{~V}$ was associated with the hydrogen adsorptiondesorpotion process. The origin of the sharp reversible peaks which appear in the second zone at a potential range of $6 \mathrm{~V}-.85 \mathrm{~V}$ indicated the formation of $\mathrm{O} \mathrm{Had}$ species. The $O H_{a d}$ species are formed at. $55 \mathrm{~V}$. The hydrogen adsorption-desorpotion process appearing in the first zone reaction unchanged with changing concentration of $\mathrm{NaOH}$ solution. On the contrary the second zone process undergoes change caused by change in $\mathrm{NaOH}$ concentration. The CVs of methanol oxidation in three different concentrations $(0.01,0.1,1 \mathrm{M})$ of $\mathrm{NaOH}$ solution show that the initial potential peak potential and potential where reaction finishes are at the same potential. But the current density of the Pt (111) surface was different depending on the $O H_{a d}$ cartage. The coverage by the $O H_{a d}$ species is probably decreased in the presence of methanol molecules. The poisoning species is formed during methanol reaction because of decreased concentration of $O H_{a d}$. The current density is decreased and featureless curve is obtained. 
Prabhuram and Manoharan (1988) investigated methanol oxidation on unsupported platinum electrode in alkaline condition. The Cyclic Voltmmogram (CVs) were recorded in different electrolyte concentration of methanol. They have assumed the following mechanisms for the Methanol Oxidation Reaction (MOR) in alkaline solution are as follows Equation 1-7:

$$
\begin{aligned}
& \mathrm{Pt}+\mathrm{OH}^{-}<==>\mathrm{Pt}-(\mathrm{OH})_{a d}+e^{-} \\
& 2 \mathrm{Pt}+\mathrm{CH}_{3} \mathrm{OH}<==\mathrm{Pt}-\mathrm{H}+\mathrm{Pt}-(\mathrm{CH} 3 \mathrm{OH})_{a d} \\
& \mathrm{Pt}-\left(\mathrm{CH}_{3} \mathrm{O}\right)_{a d}+\mathrm{Pt}-(\mathrm{OH})_{a d}<==>\mathrm{Pt}_{2}-(\mathrm{OH})_{a d}+\mathrm{H}_{2} \mathrm{O} \\
& \mathrm{Pt} t_{2}-\left(\mathrm{CH}_{2} \mathrm{O}\right)+\mathrm{Pt}-(\mathrm{OH})_{a d}<==\mathrm{Pt}-(\mathrm{CHO})_{a d}+\mathrm{H}_{2} \mathrm{O} \\
& \mathrm{Pt} t_{3}-(\mathrm{CHO})_{a d}+\mathrm{Pt}-(\mathrm{OH})_{a d}<==>\mathrm{Pt} t_{3}-(\mathrm{CO})_{a d}+2 \mathrm{Pt} \\
& \mathrm{Pt} t_{2}-(\mathrm{CO})_{a d}+\mathrm{Pt}-(\mathrm{OH})_{a d}<==>\mathrm{Pt}-(\mathrm{COOH})_{a d}+2 \mathrm{Pt} \\
& \mathrm{Pt}-(\mathrm{COOH})_{a d}+\mathrm{Pt}-(\mathrm{OH})_{a d}<==>2 \mathrm{Pt}+\mathrm{CO}_{2}+\mathrm{H}_{2} \mathrm{O}
\end{aligned}
$$

Becerik (1999) had studied electro-oxidation of D. gulcose, formic acid and methanol as a fuel in alkali medium using as Pt-Pd as electrode. Voltmmogram have shown that the electrocatalytic activity of a palladium electrode for D. glucose is less than that of a platinum electrode. This type of deactivation may be due to the formation of strongly poisoning intermediates or the accumulation of weakly bound intermediates derived from D. glucose or other reasons, e.g., ageing of the electrode surface structure. Similar effects are also observed for the oxidation of $\mathrm{HCOOH}$ in Pt-Pd alloys. $\mathrm{Pd}$ dissolution is found to be more relevant in processes responsible for the high oxidation charges observed for the alloy with a high Pt content. The oxidative properties of Pd (II) ions in a heterogeneous reaction with electro formed $\mathrm{HCOOH}$ intermediates are therefore taken into account to explain the enhancement of the Pt-Pd alloy electrode performance. Increased activity can also be expected for the electro-oxidation of $\mathrm{D}$. glucose in the case of a surface composition rich in $\mathrm{Pt}$, because the surface concentration of adsorbed residues on $\mathrm{Pt}$ sites may be lowered by the dissolved Pd (II) species. Thus, a synergistic effect will need to obtain additional kinetics and mechanistic information on this reaction. The cyclic voltmmogram help in assessing reaction mechanism intermediate and poisoning species. It can suggest suitable combination of electrode material and electrolyte/fuel mixture such that the redox reaction occurs at lowest potential and that the formation of poisoning species is prevented.
The existence of the reactive intermediated and the inactive intermediated (Poisoning species) generated during alcohol (methanol, ethanol) electro-oxidation in an alkaline solution suggested a dual path reaction mechanism which is summarized as (Tripkovic et al., 2001) proposed the following general mechanism for the alcohol electro-oxidation on nobler metal catalyst in alkaline medium Equation 8-11:

$$
\begin{aligned}
& R-\mathrm{COH}+\mathrm{OH}^{-}<==>R-\mathrm{CO}_{a d}+\mathrm{H}_{2} \mathrm{O}+e^{-} \\
& \mathrm{OH}-<==>\mathrm{OH}_{a d}+e^{-} \\
& R-\mathrm{CO}_{a d}+\mathrm{OH}_{a d}<==>R-\mathrm{COOH} \\
& R-\mathrm{COOH}+\mathrm{OH}_{a d}<==>R-\mathrm{COO}^{-}+\mathrm{H}_{2} \mathrm{O}
\end{aligned}
$$

The adsorption of alcohol on catalyst site initiates dehydrogenation reaction where alcohol reacts with hydroxyl ion to produced water molecules and electron. The adsorbed $O H_{a d}$ react with adsorbed alcohol molecules to produced acid. The acid resides as anion in the electrolyte.

Gupta et al. (2004) reported the cleavage of C-C bond in ethanol electro-oxidation by $\mathrm{CuNi} / \mathrm{PtRu}$ in alkaline medium. They have observed the presence of slight amount of acetaldehyde and evolution of $\mathrm{CO}_{2}$ in alkaline condition at $20-60^{\circ} \mathrm{C}$. As stated earlier the most serious problem in alcohol oxidation is the $\mathrm{CO}_{2}$ contamination of alkaline and the carbonate ion formation. The problem may be overcome by using circulating electrolyte (Kordesch et al., 2004; Gouerec et al., 2004). Verma et al. (2005b) Prepared $\mathrm{Pt}-\mathrm{ZrO}_{2} / \mathrm{C}$ catalysts and compared with $\mathrm{Pt} / \mathrm{C}(20 \mathrm{wt} \% \mathrm{E}-\mathrm{TEK})$ in terms of the electrochemical activity for ethanol oxidation using Cyclic Voltammerty (CV), Tafel plot and electrochemical impedance spectroscopy in alkaline solutions. All the results showed that $\mathrm{Pt}-\mathrm{ZrO}_{2} / \mathrm{C}$ gave higher catalytic activity for ethanol electro-oxidation. The effect of $\mathrm{Pt}-\mathrm{ZrO}_{2}$ molar ratio on the catalytic activity was also investigated by $\mathrm{CV}$ and the lowest peak potential for ethanol electro-oxidation appeared at the molar ratio of 1: 4 .

Verma et al. (2005a) introducing the anode which is prepared by dispersing platinum and activated carbon in Nafion (R) (DuPont USA) dispersion and placing it onto a carbon paper (Lydall, USA). Finally prepared anode material was pressed onto $\mathrm{Ni}$ mesh and sintered to produce the required anode. The maximum power density of $16.5 \mathrm{~mW} / \mathrm{cm}^{2}$ is methanol produces 31.5 $\mathrm{mW} / \mathrm{cm}^{2}$ of maximum power density at $44 \mathrm{~mA} / \mathrm{cm}^{2}$ of current density at $60^{\circ} \mathrm{C}$. The results obtained showed that the AFC could accept multifuels.

Chen and Shen (2006) introduced conducting carbon matrix with macroporous and mesoporous bimodal pore 
structure has been fabricated by combining the templating and sol-gel methods. The further surface modify by Pt-Co catalyst results in a high activity towards the ethanol oxidation in alkaline solution. The high-performance is believed due to the reduction of the liquid sealing effect. The materials with bimodal structure have the advantages that the reagents and products can transfer not only through macropores but also from mesopores. These electrodes are potentially used in liquid, fuel cells. The anode electrode with such highly porous structure will reduce the liquid sealing effect, in consequence, improves the cell performance.

\section{Cathode Electrode}

Cathode is second part of the fuel cell in which reduction kinetic reaction is occurs to increase the reaction kinetic of oxygen reduction of oxygen a non-noble elecrocatalyst should be used as cathode. The use of nonnoble metal take place of platinum as electro-catalyst at cathode makes the alkaline fuel cell cheaper.

Gojkovic et al. (1999) proposed that carbon is the active material for oxygen reduction reaction that might be obtained by heat treatment of different $\mathrm{Fe}$ or $\mathrm{CO}$ and Ni precursors on high surface. They have presented a comprehensive electrode-chemical study of oxygen reduction on iron (iii) Teramethoxyphenyl Propylene Chloride (FeTMPP-Cl) adsorbed on the Black Pearis (BP) carbon and heat treated up to $1000^{\circ} \mathrm{C}$.

The reaction kinetics in both acid and alkaline solution using heat-treated catalyst is reported. The cyclic voltmmogram were recorded with oxygensaturated solution of $0.1 \mathrm{M} \mathrm{H}_{2} \mathrm{SO}_{4}$ of $0.1 \mathrm{M} \mathrm{NaOH}$ in 1 $\mathrm{M}$ methanol to study the effect of different anions and oxygen reduction. No trace of methanol oxidation current was observed. The reaction rate of oxygen reduction was not influenced by the presence of methanol either in acidic or alkaline solution showing that the elecrocatalyst is methanol tolerant. Further the oxygen reduction reaction is not influence by the presence of sulphate, perchloride of phosphate anions. The number of electrode liberated per molecules of oxygen was estimated to be between 8.41 and 4 depending on electrode potential.

Ponce et al. (2001) studied the oxygen reduction reaction and the oxygen evolution reaction on mixed oxide NixAlxMnO $\mathrm{O}_{2}$. The substitution of $\mathrm{Al}$ by $\mathrm{Ni}$ increases the catalyst activity the maximum being exhibited by $\mathrm{Ni}$ oxide as electrocatalysis were found active toward oxygen reduction and evolution reaction (Rashkova et al., 2002). Wu et al. (2006) synthesized non-porous amorphous manganese dioxide by the mean of aqueous redoxsol-gelroute. The catalyst was analyzed using oxygen or nitrogen saturated $\mathrm{KOH}$ solution through cyclic voltammerty they pointed out that only one reduction peak is obtained and the second peak could not be obtained because of the range of potential chosen.

Demarconnay et al. (2004) estimated absent four electron evolved per oxygen molecules reduced on $\mathrm{Ag}$ catalyst. The nickel or cobalt based elecrocatalyst showed poor activity of oxygen reduction reaction in alkaline medium. The oxygen reduction on nickel or cobalt material via two-electron mechanism producing hydrogen peroxide as main product on the other hand Spinel of cobalt and nickel oxide $\mathrm{NiCO}_{3} . \mathrm{xO}_{4}$ $(\mathrm{O}<\mathrm{H}<1)$ showed a better activity towards oxygen reduction-reaction in alkaline $\mathrm{Via}$ the 4-electron path way (Wagner et al., 2004) prepared cathode using silver catalyst on a high surface area porous electrode bonded with PTFE by a cold rolling process. They found a decreased in electro-chemical performance during oxygen reduction at $70^{\circ} \mathrm{C}$ in $30 \mathrm{wt} \% \mathrm{KOH}$. The linear decreased of the electro-chemical performance has been found with a gradient of approximately 20microV $\mathrm{h}^{-1}$ in an operation period of 5000 . The total voltage loss was approximately $100 \mathrm{mv}$ which is a 12$15 \%$ of cell voltage in $5000 \mathrm{~h}$ operation time.

Verma et al. (2005a) studied performance of alkaline fuel cell with using three different fuels, e.g., methanol, ethanol and sodium borohydride. The cathode catalyst $\mathrm{MnO}_{2} / \mathrm{C} / \mathrm{Ni}$ was used as standard (Electro-ChemTechnic, UK) cathode for all the fuels. Fresh mixture of electrolyte, potassium hydroxide $(5 \mathrm{M})$ and fuel $(2 \mathrm{M})$ was fed to AFC and withdrawn at a rate of $1 \mathrm{~mL} / \mathrm{min}$. The performance of the fuel cell is measured in terms of open-circuit voltage and current-potential characteristics. A single peak in the cyclic voltmmogram suggests that a four-electron pathway mechanism prevails during oxygen reduction. This is substantiated by calculating the number of electrons involved per molecule of oxygen that are reacted at the $\mathrm{MnO}_{2}$ cathode from the oxygen consumption data for different fuels. The results show that the power density of the fuel cell increases with increase in $\mathrm{MnO}_{2}$ loading to a certain limit but then decreases with further loading. The maximum power density is obtained at $3 \mathrm{mg} \mathrm{cm}^{-2}$ of $\mathrm{MnO}_{2}$ for each of the three different fuels.

Meng and Shen (2006) used tungsten carbide nanocrystals for the electroreduction of oxygen in alkaline solution. These Pt-free electrocatalysts show high activities similar to those of Pt-based electrocatalysts. The kinetic parameters and the reaction mechanism for ORR are determined by RRDE. The enhancement of the activity is the evidence of synergetic effect. The novel elecrocatalyst shows unique selectivity towards the electroreduction of oxygen and is immune to methanol, ethanol, isopropanol and glycerol. Such low cost electrocatalysts can be potentially applied to anion exchange membrane alcohol fuel cells, alcohol monitors and metal-air batteries. 


\section{Electrolyte}

Electrolyte is a material that conducts electric current. The alkaline electrolyte has several distinct advantages over acid electrolyte. The most notable advantage is the oxidation of fuel in alkaline solution by the non-noble metal catalyst is as active as noble metal catalyst.

The other major advantage of alkaline solution is the absence of electrode poisoning form the reaction intermediates vielstich in (Kordesch et al., 2004) had chosen $\mathrm{KOH}$ as an electrolyte over $\mathrm{NaOH}$ because of its over potential particularly at cathode side.

The draw back of the alkaline electrolyte is progressive "carbonate" of the solution due to carbon dioxide produced by the reaction product of organic fuel oxidation as well as $\mathrm{CO}_{2}$ from air. The most probable electrochemical oxidation reaction of methanol in alkaline is given by (Kordesch et al., 2004) Equation 12:

$$
\mathrm{CH}_{3} \mathrm{OH}+8 \mathrm{OH}^{-}=>\mathrm{CO}_{3}^{2-}+6 \mathrm{H}_{2} \mathrm{O}+6 e^{-}
$$

The reaction has the effect of reducing the number of hydroxyl ion available for reaction at the electrode. Further it reduces the ionic conduction of the electrolyte solution.

In a very concentrated electrolyte solution it may also have the effect of blocking the pore of the Gas Diffusion Layer (GDL) by the precipitation of $\mathrm{K}_{2} \mathrm{CO}_{3}$ salt. Gulzow and Schulze (2004) reported that although carbon dioxide poisoning decreases the alkaline fuel cell performs it does not cause any degradation of the electrodes.

Even after thousand of hours of operation in carbon dioxide rich atmosphere no. additional electrode degradation like deposition of $\mathrm{K}_{2} \mathrm{CO}_{3}$ was observed. Al-Saleh et al. (1994) showed that the concentration up to $1 \%$ carbon dioxide in the oxidant steam to Ag/PTEE electrode did not affect the cell performance over a period of $200 \mathrm{~h}$. The most probable reason for the decrease in the cell performance is the change in electrolyte composition. The conversion of the electrolyte from $\mathrm{KOH}$ to $\mathrm{K}_{2} \mathrm{CO}_{3}$ by the absorption of carbon dioxide slows down the rate of oxidation of fuel the anode., Gulzow and Schulze (2004). In addition decreased electrolyte conductivity also increases the ohmic polarization leading to lower cell efficiency.

A permanent solution to the above problem must be look in to such that the direct alcohol alkaline fuel cell commercialization is possible. Some effort are being made to address the problem of carbon dioxide poisoning in alkaline fuel cell. Molecular sieves and polymeric membrane are being discussed for $\mathrm{CO}_{2}$ separation from air. At present these membranes required large area to bring down the $\mathrm{CO}_{2}$ level up to $10 \mathrm{ppm}$ from $300 \mathrm{ppm}$ at low gas velocities. Another alternative proposed is using $\mathrm{CO}_{2}$ which involves the synergistic possibility of using liquid hydrogen to condense the carbon dioxide out of the air. Ahuja and Green (1996; 1998) discussed this at length and developed a model of the heat exchange required for the purpose. This solution presents low parasitic energy consumption but the condensation and re-vaporization of water and $\mathrm{CO}_{2}$ makes the structure complicated.

Mclean et al. (1995) mentioned that the removal of the $0.03 \% \mathrm{CO}_{2}$ from the air could be accomplished by chemical absorption in a tower filled with "Soda Lime". One kilogram of soda lime has the ability to clean 1000 $\mathrm{m}^{3}$ of air and reduces $\mathrm{CO}_{2}$ from 0.03 to $0.001 \%$. The only method commercially employed to alleviate the oxidation side carbon dioxide poisoning is $\mathrm{CO}_{2}$ scrubbing using soda lime technically soda lime method work but it required periodic maintains resulting high operation cast over the lifetime of fuel cell.

The oxidation of alcohol (like methanol) produced carbon dioxide at the anode and hence contributes to the carbon dioxide poisoning in the fuel cell. Morallon et al. (1995) studied methanol electro-oxidation on platinum in $\mathrm{Na} 2 \mathrm{CO} 3$ and $\mathrm{NaOH}$ medium and found no major difference was in the deactivation of the electrode. Thus deactivation was due to the structural modification of the electrode surface by the adsorbed species.

Tripkovic et al. (2001) studied the oxidation of methanol in different concentration of bicarbonate, carbonate and sodium hydroxide solution. The basic voltmmogram were found similar except some what difference in position and peak current value. The removal of carbonate from cathode by mean of electrochemical method is received by (Mclean et al., 1995). In the electrochemical method a large current is drawn from the fuel cell which reduces the $\mathrm{OH}^{-}$ concentration at the anode. The carbonate ion migrates from cathode to anode due to anion concentration gradient thus carbonic acid at the anode is produced. Further increase in the current density electrolytes carbonic acid and $\mathrm{CO}_{2}$ escapes out from the solution. Author suggested that by recirculating electrolyte not only removes the reaction heat from the system but it also helps to remove the carbonate externally from the solution.

Prabhuram and Manoharan (1998) showed that right combination of $\mathrm{KOH}$ and methanol suppresses the formation of oxide layer intermediated organic species and poisoning species on the electrode surface this improving the methanol oxidation reaction performance. They have shown that equimolar mixture of methanol and $\mathrm{KOH}$ give the maximum current densities.

Wang et al. (2003) also used anion exchange membrane for the feasibility analysis of direct methanol fuel cell in the presence of carbonate and bicarbonate solution Cohen et al. (2005; Verma et al., 2005b) introduced a dual electrolyte $\mathrm{H}_{2} / \mathrm{O}_{2}$ fuel cell system 
employing a planar microfluidic membraneless fuel cell and compared to single electrolyte $\mathrm{H}_{2} / \mathrm{O}_{2}$ systems under analogous conditions. The fuel is $\mathrm{H}_{2}$ dissolved in $0.1 \mathrm{M} \mathrm{KOH}(\mathrm{pH} \mathrm{13})$ and the oxidant is $\mathrm{O}_{2}$ dissolved in $0.1 \mathrm{M} \mathrm{H}_{2} \mathrm{SO}_{4}$ ( $\left.\mathrm{pH} 0.9\right)$, comprising a system with a calculated thermodynamic potential of $1.943 \mathrm{~V}$ (when I $\mathrm{M} \mathrm{H}_{2}$ and $\mathrm{O}_{2}$ concentrations are assumed). This value is well above the calculated thermodynamic maximum potential of $1.229 \mathrm{~V}$ for an acid, or alkaline, single electrolyte $\mathrm{H}_{2} / \mathrm{O}_{2}$ fuel cell. Experimentally, open-circuit potentials in excess of $1.4 \mathrm{~V}$ have been achieved with the dual electrolyte system. This is a $500 \mathrm{mV}$ increase in the open circuit potentials observed for single electrolyte $\mathrm{H}_{2} / \mathrm{O}_{2}$ systems also studied. The dual electrolyte fuel cell system shows power generation of $0.6 \mathrm{~mW} / \mathrm{cm}^{2}$ from a single device, which is nearly $0.25 \mathrm{~mW} / \mathrm{cm}^{2}$ greater than the values obtained for single electrolyte $\mathrm{H}_{2} / \mathrm{O}_{2}$ fuel cell systems studied. Micro-channels of varying dimensions have been employed to study both the single and dual electrolyte $\mathrm{H}_{2} / \mathrm{O}_{2}$ systems. Channel thickness variation and the flow rate dependences of power generation are also addressed.

The studied immobilized electrolyte composite membranes prepared with a three-layer structure that has a porous intermediate layer and two solid surface layers using glutaraldehyde as cross linking agent. Potassium hydroxide has been incorporated into the porous intermediate layer of the composite membranes as ionic functionality by using a two-step pathway. The ionic conductivity of these composite membranes is investigated using impedance spectroscopy. It is found that some dried composite membranes with a load of KOH between 5.5 and 8.5 wt.\% can show a conductivity in the range of semi-conductors (around $10^{6} \mathrm{~S} \mathrm{~cm}^{1}$ ) and their conductivity can reach about $10^{2} \mathrm{~S} \mathrm{~cm}^{1}$ after being hydrated for $1 \mathrm{hr}$ at room temperature. Main mechanical properties; tensile strength, breaking elongation and modulus has been evaluated. The obtained results suggested that in order to ensure the composite membranes to have desired mechanical properties and higher conductivity and to be possibly used in an alkaline fuel cell, the ratio of glutaraldehyde to chitosan should be selected between 4 and 5 wt.\% and the content of potassium hydroxide loaded inside the inner layer should be controlled below $6 \mathrm{wt} . \%$

$\mathrm{Wu}$ et al. (2006) prepared of alkaline, high ionic conducting membrane separators with lower cost using non-woven Poly Propylene/Poly Ethylene (PP/PE) core-shell sheet membranes. Sulfonation was employed to enhance the membrane anionic conductivity by improved hydrophilicity and more amorphous structure of the polymer. The characteristic properties of these membrane separators have been studied by ac impedance, contact angle measuring system, Differential Scanning Calorimeter (DSC), Thermo Gravimetric Analysis (TGA), Infrared spectroscopy (IR), Elemental Analysis (EA), stressstrain test, X-Ray Diffraction (XRD) and Scanning Electron Microscope (SEM). The incorporation of sulfonic acid groups in the polymer membranes was evident by the IR spectroscopy. The results showed that the sulfonation treatment reaction was very effective in increasing the surface hydrophilicity of the non-woven membranes. Suitable sulfonation process could increase the room temperature anionic conductivity of the membranes from 0.0088 to 0.0175 $\mathrm{S} \mathrm{cm}^{1}$. The sulfonated membranes showed limited decline in thermal resistance (4\%) and mechanical strength $(21 \%)$. Further study on the solid-state zincair cells assembled for these membrane separators also exhibited an improved battery power density by $69 \%$, from 16 to $27 \mathrm{~mW} / \mathrm{cm}^{2}$.

\section{Cellperformance}

Cell performance depends upon many reaction parameters that occur between different fuels and oxygen, electrolyte used in the cell and the temperature at which the reaction is carried out.

\section{Fuel Concentration}

Fuel is the supporter for the fuel cell which donates hydrogen to the reaction to increase the rate if hydrogen rich compound is used. Verma and Basu (2005c) used methanol and ethanol as fuel for alkaline fuel cell. The effect of alcoholic fuel concentration on $\mathrm{CV}$ in $1 \mathrm{M} \mathrm{KOH}$ solution is shown in the Fig. 2 for the methanol.

The peak current decreases with the increase in methanol concentration. However the current density increases with the increase in methanol concentration form $0.5 \mathrm{M}$ to $1 \mathrm{M}$ and on further increase in concentration of methanol to $2 \mathrm{M}$ the current density increases slightly. In this case initial increase in current density may be because of the increase in methanol concentration. But the availability of $\mathrm{OH}-$ ion at catalyst site decrease with the further increase in methanol concentration. As a result the methanol oxidation reaction suffer due to lesser availability of adsorbed $\mathrm{OH}$-on the catalyst sites. Consequently the current density at higher methanol concentration decrease. A similar trend is observed for the ethanol electro-oxidation shown in Fig. 3. On increasing the concentration of ethanol from $5 \mathrm{M}$ to $1 \mathrm{M}$ the current density increases as more ethanol molecules are available for oxidation. However the peak current density decrease when the concentration is further increased to $0.03 \mathrm{M}$. 


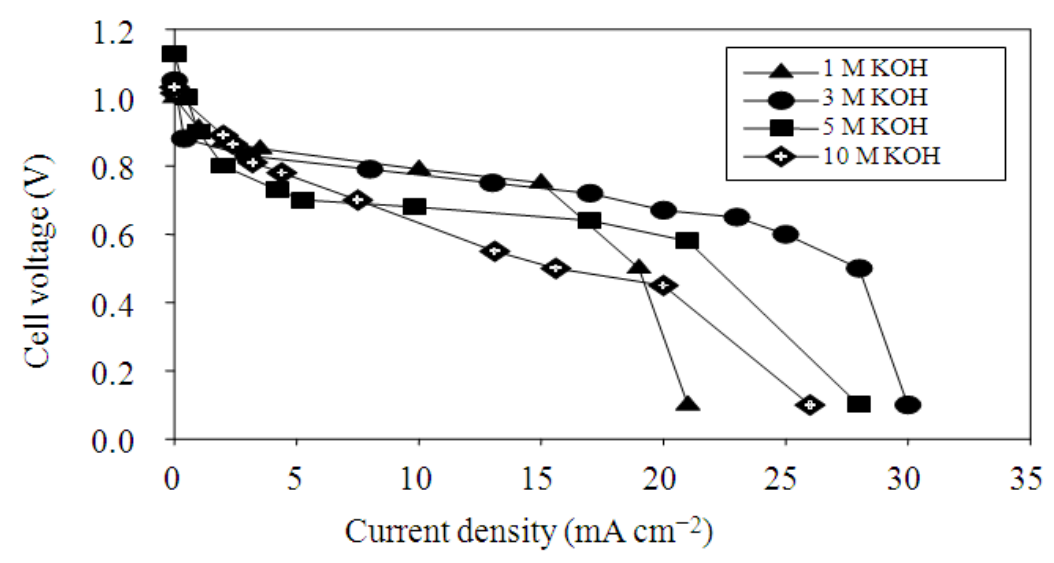

Fig. 2. Current density-voltage variations at four different $\mathrm{KOH}$ concentrations for $2 \mathrm{M}$ ethanol in alkaline fuel cell at $25^{\circ} \mathrm{C}$, Anode: $\mathrm{Pt}$ Black; Cathode: $\mathrm{MnO}_{2}$

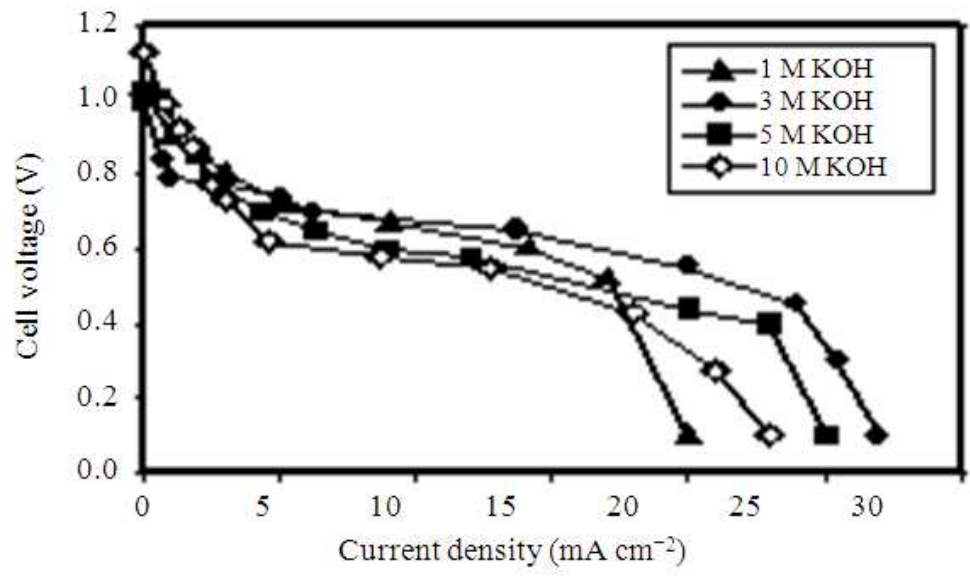

Fig. 3. Current density-voltage variations at four different $\mathrm{KOH}$ concentrations for $2 \mathrm{M}$ ethanol in alkaline fuel cell at $25^{\circ} \mathrm{C}$, Anode: $\mathrm{Pt}$ Black; Cathode: $\mathrm{MnO}_{2}$

\section{Electrolyte Concentration}

A higher current flow (amperage) through the cell means it will be passing more electrons through it at any given time. This means a faster rate of reduction at the cathode and a faster rate of oxidation at the anode. This corresponds to a greater number of moles of product. The amount of current that passes depends on the concentration of the electrolyte, it show different value in different concentration of electrolyte used. Verma and Basu (2005c) used potassium hydroxide as electrolyte because $\mathrm{KOH}$ plays a dual role in fuel electro-oxidation in the form of $\mathrm{OH}_{a d}$ species first play the role of an active intermediate in alcohol oxidation and second help in the form of oxide species. This is responsible for the inhibition of the fuel oxidation reaction. He showed that the cyclic voltmmogram for methanol and ethanol with different concentration of $\mathrm{KOH}$ it is seen that the peak current density increase in $\mathrm{KOH}$ concentration. It is because the increase in
$\mathrm{KOH}$ concentration increases the $O H_{a d}$ species on the electrode which in turn increases the electro-oxidation and the current density. However the current density decreases on further increase in $\mathrm{KOH}$ concentration.

The probable reason may be the higher adsorption of hydroxyl ion on the catalyst site. At a higher concentration of $\mathrm{KOH}$ promotes the PtO layer formation and this hinders the formic acid formation reaction.

The formic acid and formation reaction is suppressed at low $\mathrm{KOH}$ concentration due to unavailability of $\mathrm{OH}_{a d}$ species. CVs obtained here for methanol electro-oxidation in alkaline medium are shown in Fig. 4 same to be obtained by several investigator (Prabhuram and Manoharan, 1998; Gasteiger et al., 2003a; 2003b). A similar trend was also observed in the case of $2 \mathrm{M}$ ethanol at different concentration of $\mathrm{KOH}$ solution shown in Fig. 5 and the density increase with the increase in concentration of $\mathrm{KOH}$ from $1 \mathrm{M}$ to $10 \mathrm{M}$ and with the further increase in $\mathrm{KOH}$ concentration peak current density decrease. 


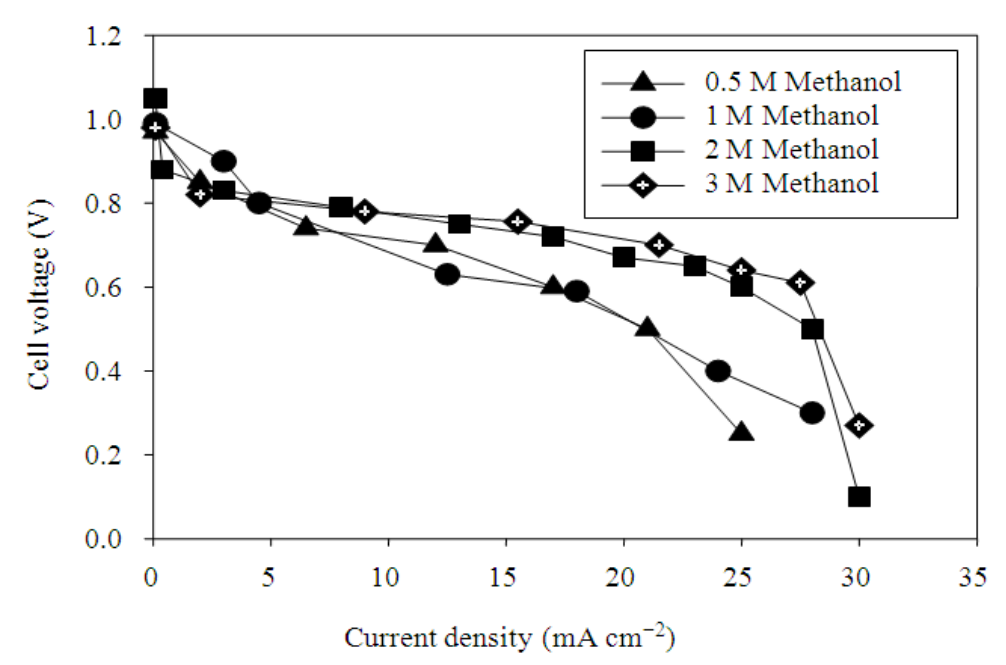

Fig. 4. Current density-cell voltage characteristics at different methanol concentration in $3 \mathrm{M} \mathrm{KOH}$ electrolyte in alkaline fuel cell at $25^{\circ} \mathrm{C}$, Anode: Pt Black; Cathode: $\mathrm{MnO}_{2}$

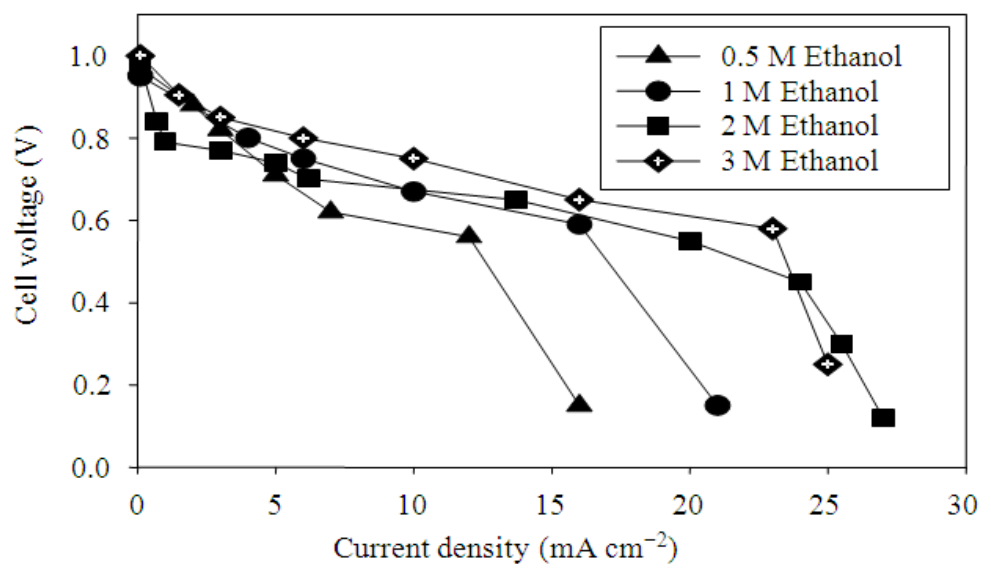

Fig. 5. Current density-cell voltage characteristics at different ethanol concentration in $3 \mathrm{M} \mathrm{KOH}$ electrolyte in alkaline fuel cell at $25^{\circ} \mathrm{C}$, Anode: Pt Black; Cathode: $\mathrm{MnO}_{2}$

\section{Temperature}

In the cell reaction process becomes faster when the fuel entering and electrolyte is warm rather than cold. So the temperature plays an important role to develop the voltage across terminal. Verma et al. (2005b) found out that for methanol and ethanol fuel at 25,45 and $65^{\circ} \mathrm{C}$ the performance increases with the increase in temperature because of decrease in activation over potential concentration and mobility at higher temperature which shown in Fig. 6 and 7.

The fuel cell was designed for low temperature operation and its design restricts the operation of fuel cell for longer time and higher temperature. Betty et al. (2006) studied that the voltage output increases with an increase in temperature. The output power also increases due to the improved reaction kinetics. There is a decrease in the ohmic polarization because of the increased conductivity of the electrolyte at higher temperatures. At the same time the activation polarization also decreases because of improved kinetics at higher temperature. The contributions to the change in current/voltage behavior can be determined if one considers the total polarization of the electrode to be given by expression Equation 13:

$$
\begin{aligned}
& \eta t o t a l=\frac{2.303 R T}{\alpha z F} \log \left(\frac{i}{i_{o}}\right) \\
& -\frac{2.303 R T}{\alpha z F} \log \left(1-\frac{i}{i_{L}}\right)+i\left(R_{s}+R_{f}\right)
\end{aligned}
$$

where, $i_{o}$ is the exchange current density; $\alpha$ the transfer coefficient; $z$ the number of electrons; $F$ the Faraday's constant; $R$ the gas constant; $T$ the temperature; $R_{\mathrm{S}}$ the solution resistance; $R_{f}$ the film resistance 0.3 . 


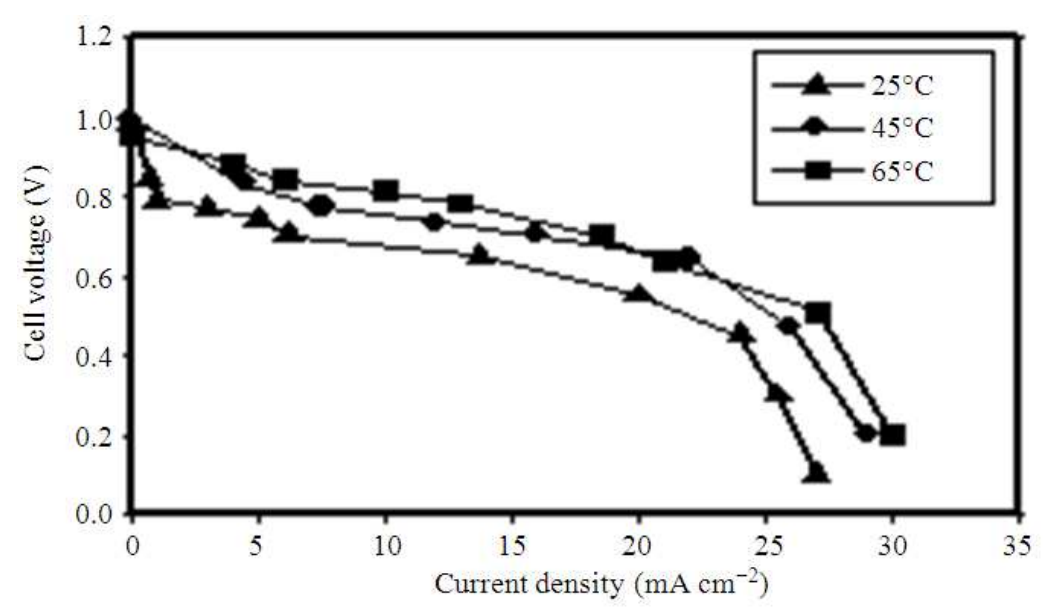

Fig. 6. Current density cell voltage characteristics for $2 \mathrm{M}$ methanol/3 $\mathrm{M} \mathrm{KOH}$ fuel/electrolyte mixture at different temperature in alkaline fuel cell. Anode: Pt Black; Cathode: $\mathrm{MnO}_{2}$

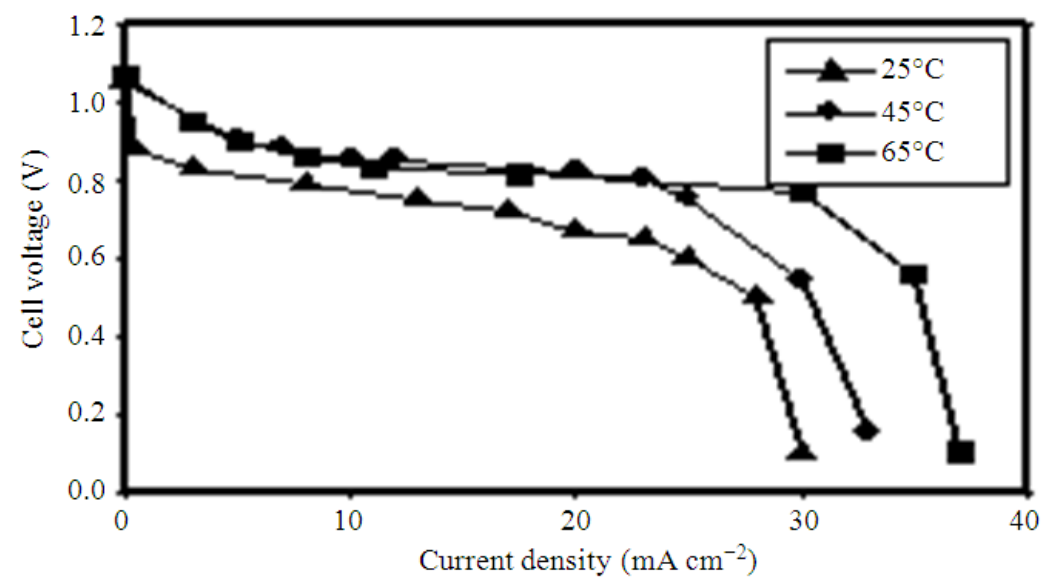

Fig. 7. Current density-cell voltage for $2 \mathrm{M}$ ethanol/3 $\mathrm{M} \mathrm{KOH}$ Fuel/electrolyte mixture at characteristics different temperature in alkaline fuel cell. Anode: Pt Black; Cathode: $\mathrm{MnO}_{2}$

Making some basic assumptions (not diffusion limited, not passivated, no change in reaction mechanism/activation step), this can be reduced to expression Equation 14:

$\eta$ total $=\frac{2.303 R T}{\alpha z F} \log \left(\frac{i}{i_{o}}\right)+i R_{S}$

The actual operating temperature within the fuel cell is not $70^{\circ} \mathrm{C}$. In fact, the operating temperature within the fuel cell is dependent on the amount of current that is drawn from the fuel cell because the fuel cell is a load following device. At currents of $0 \mathrm{~A}$ to $12 \mathrm{~A}$, the operating temperature within the cell is 40 to $50^{\circ} \mathrm{C}$. From $12 \mathrm{~A}$ to $18 \mathrm{~A}$, the temperature is 50 to $60^{\circ} \mathrm{C}$. For currents of $18 \mathrm{~A}$ to $23 \mathrm{~A}$, the temperature is 60 to $70^{\circ} \mathrm{C}$. Finally, for currents of $23 \mathrm{~A}$ to $25 \mathrm{~A}$, the temperature within the cell reaches $70^{\circ} \mathrm{C} \pm 2^{\circ} \mathrm{C}$.
Thus the study is done up to $72^{\circ} \mathrm{C}$ but the emphasis is given to $25^{\circ} \mathrm{C}$ temperature. That why application of this kind to fuel cell is thought to be powering portable electronic equipment likes laptop, mobile. thus in the subsequent experiment the fuel cell was operated at $25^{\circ} \mathrm{C}$.

\section{Commerial Value}

Fuel cell plays a vital role for the production of power generation in the following areas:

- As a stationary source: It can be applied as a fuel cell system (2500 or even higher) in hospitals, hotels, offices and schools. Because in these fields power generation is not possible; and fuel cell fulfills the demand of electricity

- In transportation purpose: As a fuel for bus, cars, two wheelers. All the major automotives 
manufacture have a fuel cell vehicle either in developed or in the testing right normally they commercial till up to 2010

- In the field of portable power: The fuel cell will give better option to electronic and telecommunication world. It may be used as a source of power for laptop, pager and mobile phone. It does not require recharging the cell and provides long cell life as compared to the other batteries

In the field of land filled side fuel is also applied basically electricity is generate either hydro-power or thermal-power they are not eco-friendly but fuel cell current operated at landfill side also. It give valuable technology for reducing emission and generating power for, the methane gas. In 1996 Grotron landfill had produced $600,000 \mathrm{KW}$ of electricity.

Fuel cell can used as chemical and energy cogeneration (Alaide et al., 2006) found that alkaline fuel cell have the ability to produced useful organic chemical also like hydrogen peroxide which is valuable in market. Many such examples are there where fuel cells are applied in generation of power. Fuel cell offers an opportunity for the economical growth of developing country.

\section{Conclusion}

The future of the fuel cell is impressive and impactive for power generation. It provides physical security, high reliability, fuel-flexibility, high-efficiency, environmental-benefit, motor-vehicles battery, various military applications. Further development and implement is required for the improvement of fuel cell for better results. Evolution of $\mathrm{CO}_{2}$ is poisoning in nature and should be controlled, stack design and testing is required for the production of power in $\mathrm{KW}$, Development of large scale cell industries is required so that it can be easily available and cheaper and neonstructuring should be establish for the fuel cell.

\section{Acknowledgment}

The authors acknowledge department of chemical engineering IITdelhi for providing the facilities.

\section{Author's Contributions}

All authors equally contributed in this study.

\section{Ethics}

This article is original and contains unpublished material. The corresponding author confirms that all of the other authors have read and approved the manuscript and no ethical issues involved.

\section{References}

Ahuja, V. and R.K. Green, 1998. Carbon dioxide removal from air for alkaline fuel cells operating with liquid hydrogen-a synergistic advantage. Int. J. Hydrogen Energy, 23: 131-7.

DOI: $10.1016 / \mathrm{S} 0360-3199(97) 00026-8$

Ahuja, V. and R.K. Green, 1996. $\mathrm{CO}_{2}$ removal from air for alkaline fuel cells operating with liquid hydrogen-heat exchanger development. Int. J. Hydrogen Energy, 21: 415-421. DOI: 10.1016/0360-3199(95)00101-8

Alaide, F., P.L. Cabot and E. Brillas, 2006. Fuel cells for chemicals and energy cogeneration. Rev. J. Power Sources, 153: 47-60. DOI: $10.1016 /$ j.jpowsour.2005.11.041

Al-Saleh, M.A., S. Gultekin, A.S. Al-Zakri and H. Celiker, 1994. Effect of carbon dioxide on the performance of Ni/PTFE and Ag/PTFE electrodes in an alkaline fuel cell. J. Applied Electrochem., 24: 575-80. DOI: 10.1007/BF00249861

Becerik, I., 1999. The role of electrolytic all codeposited platinum-palladium electrode on the electro oxidation of D. Gulcose in alkaline medium a synergistic effect. Turk J. Chem., 23: 57-66.

Betty, R., J.E. Cardier, E. Romano, A.L. Rothman and R. Giovannetti et al., 2006. Evidence of vascular damage in dengue disease: Demonstration of high levels of soluble cell adhesion molecules and circulating endothelial cells. Regular Articles, 13: 335-340. PMID: 17090406.

Chen, S.X. and X. Shen, 2006. Macroporous conducting matrix: Fabrication and application as electrocatalyst support. Article Electrochem. Commun., 8: 713-719. DOI: $10.1016 /$ j.elecom.2006.02.016

Cohen, J.L., D.J. Volpe, D.A. Pechenik A. Westly and H.D. Abruna, 2005. A dual electrolyte $\mathrm{H}-2 / \mathrm{O}-2$ planar membraneless microchannel fuel cell system with open circuit potentials in excess of $1.4 \mathrm{~V}$. Langmuir, 21: 3544-3550. DOI: 10.1021/la0479307

Demarconnay, J., C. Coutanceau and J.M. Leger, 2004. Electroreduction of dioxygen (ORR) in alkaline medium on $\mathrm{Ag} / \mathrm{C}$ and $\mathrm{Pt} / \mathrm{C}$ nanostructured catalysts-effect of the presence of methanol. Electrochim. Acta, 49: 4513-4521. DOI: $10.1016 /$ j.electacta.2004.05.009

Gojkovic, S.L., S. Gupta and R.F. Savinell 1999. Heattreated iron (III) tetramethoxyphenyl porphyrin chloride supported on high-area carbon as an electrocatalyst for oxygen reduction. Part II. Kinetics of oxygen reduction. J. Electroanal. Chem., 462: 63-72. DOI: 10.1016/S0022-0728(98)00390-8

Gouerec, P., L. Poletto, J. Denizot, E. SanchezCortenzon and J.M. Miners, 2004. The evolution of the performance of alkaline fuel cells with circulating electrolyte. J. Power Sources, 129: 193-204. DOI: 10.1016/j.jpowsour.2003.11.032 
Gulzow, E. and M. Schulze, 2004. Long-term operation of AFC electrodes with $\mathrm{CO}_{2}$ containing gases. J. Power Sources, 127: 243-251. DOI: 10.1016/j.jpowsour.2003.09.020

Gupta, S.S., S.S. Mahapatra and J. Datta, 2004. A potential anode material for the direct alcohol fuel cell. J. Power Sources, 131: 169-174.

DOI: 10.1016/j.jpowsour.2004.01.009

McLean, D.A., D.M. Glover, M.H. Leibowitz and H. Parry, 1995. Mutations in aurora prevent centrosome separation leading to the formation of monopolar spindles. Cell, 81: 95-105. DOI: 10.1016/0092-8674(95)90374-7

Meng, H., P.K. Shen, 2006. Novel Pt-free catalyst for oxygen electroreduction. Electrochem. Commun., 8: 588-594. DOI: 10.1016/j.elecom.2006.01.020

Morallon, E., A. Rodes, J.L. Vazquez and J.M. Perez, 1995. Voltammetric and in-situ FTIR spectroscopic study of the oxidation of methanol on Pt (hlk) in alkaline media. J. Electroanal. Chem., 391: 149-157. DOI: $10.1016 / 0022-0728(95) 03965-J$

Ponce, J., J.1. Rehspringer, G. Poillerat and J.L. Gautier, 2001. Electrochemical study of nickelaluminium-manganese spinel $\mathrm{Ni}_{\mathrm{x}} \mathrm{Al}_{1-\mathrm{x}} \mathrm{Mn}_{2} \mathrm{O}_{4}$. "Electrocatalytic properties for the oxygen evolution reaction and oxygen reduction reaction in alkaline media. Electrochim. Acta, 46: 33733380. DOI: 10.1016/S0013-4686(01)00530-8

Prabhuram, J. and R. Manoharan, 1988. Investigation of methanol oxidation on unsupported platinum electrodes in strong alkali and strong acid. J. Power Sources, 74: 54-61. DOI: $10.1016 / \mathrm{S} 0378-7753(98) 00012-3$

Rashkova, V., S. Kitova, I. Konstantinov and T. Vitanov, 2002. Vacuum evaporated thin films of mixed cobalt and nickel oxides as electrocatalyst for oxygen evolution and reduction. Electrochim. Acta, 47: 15551560. DOI: $10.1016 / \mathrm{S} 0013-4686(01) 00897-0$

Tripkovic, A.V., K.D. Popovic and J.D. Lovic, 2001. The influence of oxygen-containing species on the electrooxidation of the $\mathrm{C}_{1}-\mathrm{C}_{4}$ alcohols at some platinum single crystal surfaces in alkaline solution. Electrochim. Acta, 46: 3163-3173.

DOI: $10.1016 / \mathrm{S} 0013-4686(01) 00608-9$
Verma, A., A.K. Jha and S. Basu, 2005a. Manganese dioxide as a cathode catalyst for a direct alcohol or sodium borohydride fuel cell with a flowing alkaline electrolyte. J. Power Sources, 141: 30-34. DOI: 10.1016/j.jpowsour.2004.09.005

Verma, A., A.K. Jha and S. Basu, 2005b. Evaluation of an alkaline fuel cell for multi- fuel system. J. Fuel Cell Sci. Technol., 2: 234-237. DOI: 10.1115/1.2039955

Verma, A. and S. Basu, 2005c. Direct use of alcohols and sodium borohydride as fuel in an alkaline fuel cell. J. Power Sources, 145: 282-285. DOI: 10.1016/j.jpowsour.2004.11.071

Wagner, N., M. Schulze and E. Gulzow, 2004. Long term investigations of silver cathodes for alkaline fuel cells. J. Power Sources, 127: 264-272. DOI: $10.1016 /$ j.jpowsour.2003.09.022

Wang, Y., L. Li, L. Hu, L. Zhuang and B. Xu et al., 2003. A feasibility analysis for alkaline membrane direct methanol fuel cell: Thermodynamic disadvantages versus kinetic advantages. Electrochem. Commun., 5: 662-666. DOI: 10.1016/S1388-2481(03)00148-6

Wu, G.M., S.J. Lin and C.C. Yang, 2006. Preparation and characterization of high ionic conducting alkaline nonwoven membranes by sulfonation. J. Membrane Sci., 284: 120-127. DOI: 10.1016/j.memsci.2006.07.025

Gasteiger, H.A., W. Vielstich and A. Lamm, 2003a. Handbook of Fuel Cells: Fundamentals, Technology and Applications. 1st Edn., John Wiley and Sons, ISBN: 0470723114, pp: 230.

Gasteiger, H.A., W. Vielstich and A. Lamm, 2003b. Handbook of Fuel Cells: Fundamentals, Technology and Applications. John Wiley and Sons, ISBN-10: 0470723114, pp: 23.

Kordesch, K., M. Cifrain, G. Koscher, T. Hejze and V. Hacker, 2004. A survey of fuel cell systems with circulating electrolytes. Proceedings of the Power Sources Conference, Jun. 14-17, Philadelphia. 